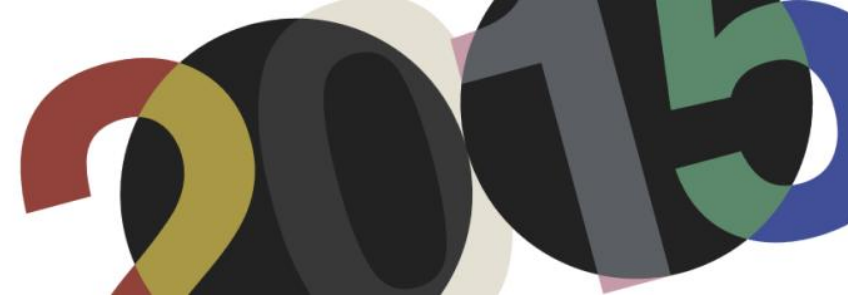

DOI: http://dx.doi.org/10.4995/LC2015.2015.938

\title{
Garder mon aile dans ta main: The genesis of the Open Hand
}

\author{
G. Sepe Camargo
}

Faculdade de Arquitetura e Urbanismo da Universidade de São Paulo

\begin{abstract}
The main hypothesis of this paper is that in the image of the Open Hand it is possible to find the reconciliation between two significant themes of the symbolic universe engendered by Le Corbusier: instrumentality and detachment. The genesis of the Open Hand is therefore to be seen as grounded among his late 1940s plastic works, which notably display the gradual movement of certain elements of figuration toward an iconic role. The hand appears as a crucial theme to Le Corbusier. Unlike other themes that have been set as pictograms - as the meander, the solar journey of 24 hours, and the bull figure -, the hand will not find its definitive form until very late in the architect's work. The hand's "other" seems to be another image from his painting: the winged figure, half woman and half animal, that appears in a wall at the Pavillion Suisse (mural, 1948) and illustrates the cover of Poésie sur Alger (1951). The image suggests an alienation from the worldly experience and the tragedy represented by the historical time, related to the volatility of natural phenomena. These two figures seem to synthesize the two attitudes governing the work of Le Corbusier thereafter. It is in Le Poème de L'Angle Droit (1947-1953) that the core of the symbolic system of Le Corbusier is found. The duality achieves its final result in the figure of the Open Hand, elected as the synthesis of the entirety of his symbolic system.
\end{abstract}

Resumen: La principal hipótesis de este trabajo es que en la imagen de la Mano Abierta es posible encontrar la reconciliación entre dos temas importantes del universo simbólico engendrada por Le Corbusier: instrumentalidad y el desapego. Por tanto, la génesis de la Mano Abierta es ser visto entre sus obras plásticas finales de 1940, que sobre todo muestran el movimiento gradual de ciertos elementos de la figuración hacia un papel icónico. La mano aparece como un tema crucial para Le Corbusier. A diferencia de otros temas que se han establecido como pictogramas - como el meandro, el viaje solar de 24 horas, y la figura del toro -, la mano no encontrará su forma definitiva hasta muy tarde en la obra del arquitecto. El "otro" parece ser una imagen de su pintura: la figura alada, mitad mujer y mitad animal, que aparece en el Pabellón Suisse (mural, 1948) e ilustra la portada de Poésie sur Alger (1951). La imagen sugiere una alienación de la experiencia mundana y la tragedia representada por el tiempo histórico, relacionado con la volatilidad de los fenómenos naturales. Estas dos figuras parecen sintetizar las dos actitudes que rigen la obra de Le Corbusier a partir de entonces. Es en Le Poème L'Angle Droit de (1947-1.953) que el núcleo del sistema simbólico de Le Corbusier se encuentra. La dualidad logra su resultado final en la figura de la Mano Abierta, elegido como la síntesis de la totalidad de su sistema simbólico.

Keywords: Open Hand; Le Poème de L'Angle Droit; Chandigarh; instrumentality; detachment.

Palabras clave: Open Hand; Le Poème de L'Angle Droit; Chandigarh; instrumentalidade; desapego.

\section{Introduction}

This paper looks into the hypothesis that the plastic work of Le Corbusier contains the genealogy of a highly elaborate symbolic system that permeates every moment of his intellectual activity. The image of the Open Hand is its decisive moment. This symbolic system is rooted in the structural change underwent by his painting in the end of the 1930s, and finds a clearer formalization in the period between 1947 and 1953.

This constellation of symbols, added to a fabric of distinct realms — such as architecture, painting, sculpture reveals one particular attribute: that this laboratory, the recherche patiente, is never detached from the figurative art, its driving force. 
The figurative is associated with personal records, travel notes, the exercise of memory, studies. Ultimately, when endowed with an iconic quality, it relates to a communicative quest. This new status seems to be embodied with a unique and radical attribute, to such extent that Le Corbusier sets out to think through painting, especially between 1947 and 1953.

As an itinerary for this paper, we track down the establishment of his symbolism in the preceding moment, illustrated by the project for the monument in memory of Vaillant-Couturier. This early moment intertwines painting and architecture - a certain painting and a certain architecture.

The reason for mentioning this particular project is twofold. First, its formalization displays symbolic concerns and also works as a counterpoint to the next period. Second, the presence of an image in the monument allows us to demonstrate the subsequent development in Le Corbusier's thinking, from the figurative to the iconic.

We then set out to exemplify the structural changes in his paintings occurring from 1938. For this purpose we describe the execution of Grafitte at Cap-Martin.

From this point, the analysis focus on the symbolism that emerges in the years between 1947 and 1953 , considering the murals in the atelier at 35 rue de Sèvres and the Pavillon Suisse in the brief interval between March and October 1948. It was a turning point, when the plastic work played a new role. The themes of these two murals are premonitory of a more precise definition, which can be found in Le Poème de L'Angle Droit. Besides this, the fact that these two murals and the publication of the text Unitél can be situated very closely in time indicates that at this point the architect was more effectively carrying out his plastic activity. In the text, published in a special issue of L'Architecture d'aujourd'hui (1948), Le Corbusier for the first time openly reproposes a chronology in which architecture and painting are not antagonists, but appear as different moments of the same research. Thereafter, the evaluation of his painting and graphic work will be increasingly frequent, and inseparable from his architectural work.

The analysis seeks to move freely across the textile established by various realms - architecture, painting, graphic art. We understand that so do symbols - even if they remain tied to the fundamental warp of the painting, seen here as an ordering matrix.

\section{An initial attempt}

It is the very nature of the symbolism labored by the architect that allows the continuous shift of themes from different linguistic domains. This symbolism is fixed in precise images. The hand is one of them.

As pointed out by Juan Calatrava, for Le Corbusier "the hand is the point of contact between the artist and the world", ${ }^{2}$ a symbol opposing the idea of hierarchy and the distinction between idea and execution bequeathed by the classical tradition.

In 1937, that image appears highlighted in the project to the monument in memory of Paul Vaillant-Couturier (Fig. 01), the socialist editor of the newspaper L'Humanité, for the town of Villejuif, near Paris

\footnotetext{
${ }^{1}$ L'Architecture d'aujourd'hui. Special issue "Le Corbusier". Paris: Editions L'Architecture d'aujourd'hui, 1948.

2 Calatrava, Juan. "La plastica de un arquitecto". In: Salvador Guerrero (Ed.), Una Casa-Un Palacio. Madrid 1928. Exhibition catalog. Madrid: Publicaciones de la Residencia de Estudiantes, 2010, pp. 182-183.
} 


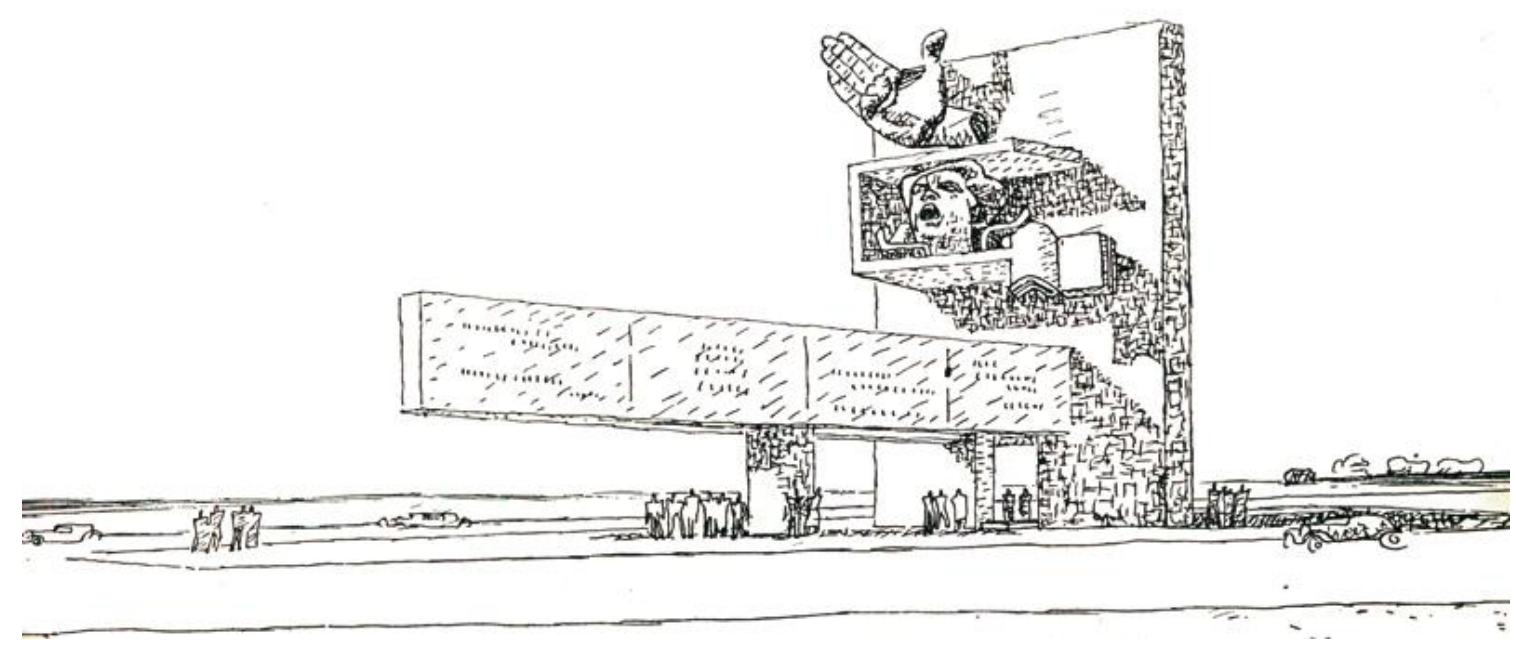

1. Monument in memory of Vaillant-Couturier. In: Mein Werk/L'Atelier de la recherche patiente. $1^{\text {st }}$ ed. Paris: Ed. Vincent Fréal, 1960

The monument consists of a concrete wall, with an equivalent proportioned volume protruded in the horizontal direction. Three images are molded in concrete: a face, an open book and a hand. The arrangement of these images, emerging from the wall, with the open hand on top of the composition, ensures a dramatic dynamism to the monument whenever it is seen by an observer in motion, from an automobile for instance.

The composition echoes the assemblage of objects characteristic of paintings such as Siphon et gants (FLC 210), from 1927: each object keeps its autonomy, as desired by the objectivity of purism. The contours of the face attached to the monument are similar to those of female figures depicted in oil paintings such as La femme au guéridon et au fer à cheval (FLC 145), from 1928. In both cases Le Corbusier is concerned about demarcate the hues from the incidence of light on the purity of the geometry that constitutes the figures. The interweaving of the objects is achieved through the consistency of the material in both cases; oil patches in contrasting colors on the paintings are comparable to the homogeneity of the concrete in the monument. The images overlap one another in a collage, maintaining the independence of the theme.

In the case of the monument, it is worth noticing the ambiguous nature of the gesture alluded to by the image of the hand, which crowns the composition. It does not match any assertive gesture of protest, which supposedly accompanies the outcry of the face below. Designed as the final image of the composition, the hand reinforces the disjunction between the elements. The hand gently juts skyward like an intermission.

This early appearance still does not conceal the subsequent role of the hand. In retrospect, it is significant of the structural change of the symbolism alluded to. A structural evolution of his art will be required to reposition the meaning of this particular figure within a larger system.

\section{Structural changes}

After his forays in the Casbah of Algiers in 1931, the compositions depicting female figures became a recurring theme in Le Corbusier's studies. 
Earlier that year, the architect had been invited by the company Amis d'Alger to deliver two lectures in the city. Although he received no official charge, the interest in Algiers prompted the drafting of the Plan Obus, presented in the following year. Between 1931 and 1942, the architect returned several times to the city and produced a significant number of other proposals, none of them executed. ${ }^{3}$

As demonstrated by Von Moos, ${ }^{4}$ in his first visit to Algiers Le Corbusier had the opportunity to make rapid sketches of female nudes. He worked on this set of drawings continuously during the subsequent years; their purpose, a larger wall composition, has never been carried out.

In several studies, the architect proceeds similarly. Each figure was individually modeled and subsequently transferred over a translucent paper sheet. The various overlapping sheets of paper allowed a better fit of the composition before the final drawing. The name mariage des contours was given to this procedure, which origins can be traced back to the still lifes of purist research.

The most accurate transposition of this working method, although not matching the previously intended project, is the panel done in 1938 for the summer house drawn by Irish designer Eileen Gray (1878-1976) for the editor of the magazine L'Architecture Vivante, Jean Badovici (1893-1956), in Roquebrune-Cap-Martin. Le Corbusier was a frequent visitor of the house during the 1930 s.

Graffite at Cap-Martin (Fig. 02), carried out without the consent of Gray, incorporates the elements that had been tested since $1931 .^{5}$

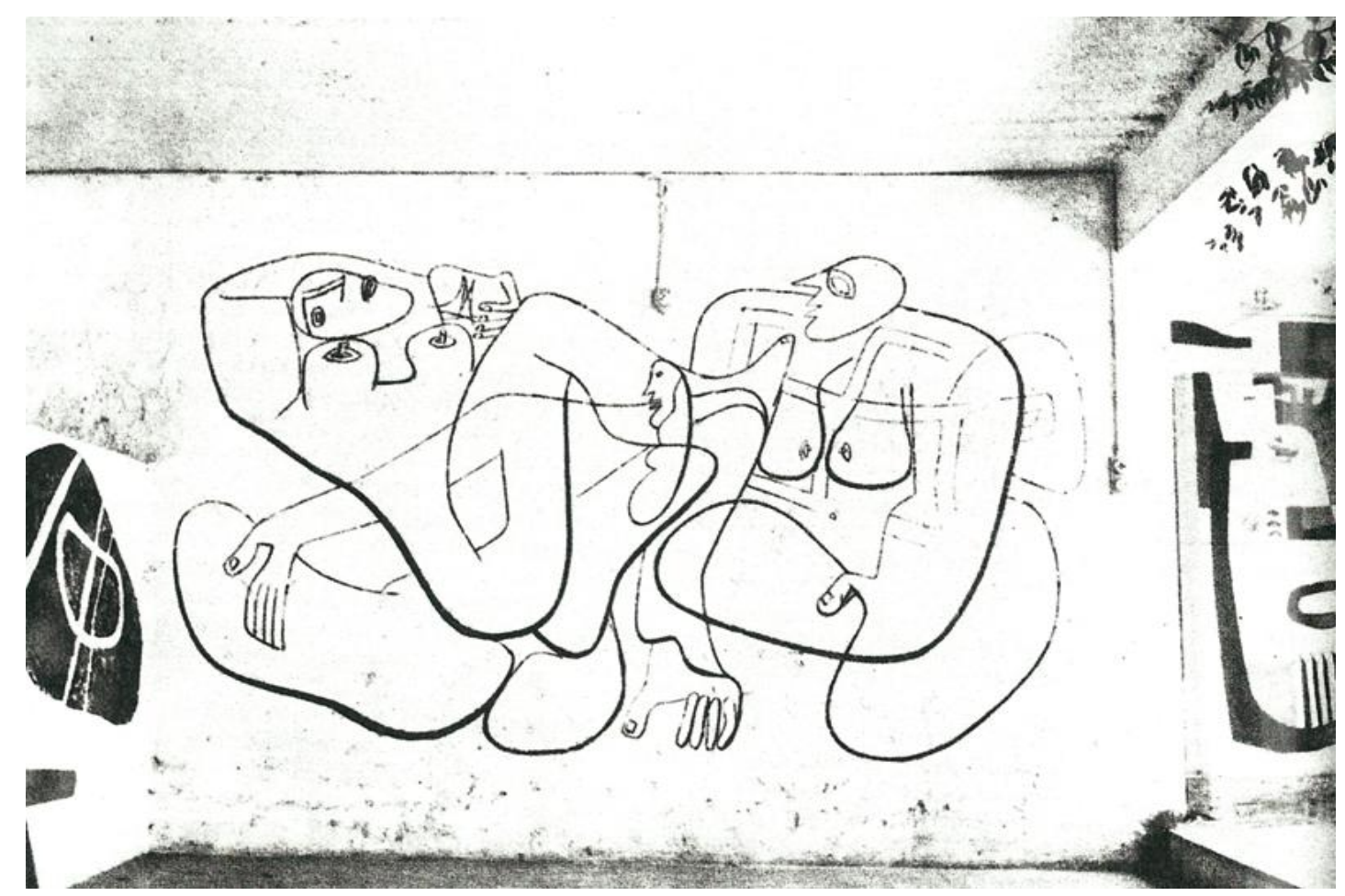

2. Graffite at Cap-Martin. In: Mein Werk/L'Atelier de la recherche patiente. $1^{\text {st }}$ ed. Paris: Ed. Vicent Fréal, 1960

\footnotetext{
${ }^{3}$ For a detailed account of Le Corbusier experience in North Africa, see: Mary McLeod "Le Corbusier and Algiers"In: Oppositions 19-20. Cambridge, Massachusetts: MIT Press, 1980, pp. 55-85.

${ }^{4}$ Von Moos, Stanislau. “Mariage des Contours”. In: Oppositions 19-20. Cambridge, Massachusetts: MIT Press, 1980, pp. 87107.

${ }^{5}$ For a detailed account of this episode, see: Colomina, Beatriz. Privacy and Publicity. Architecture as Mass Media. $1^{\mathrm{st}}$ ed. Cambridge, Massachusetts: MIT Press, 1996.
} 
On the wall, the detailing of the hands contrasts with the strong line that delineates the three images. The hands seem to define the limits of the composition: the four fixed points or pivots around which the images are organized.

The mural also illuminates the internal hierarchy of the elements in Le Corbusier's paintings from that period. Von Moos points out that the exposure of Guernica in the Spanish Pavilion at the International Fair of Paris, held in the year preceding the preparation of Graffite at Cap-Martin, had strongly impressed Le Corbusier, especially because Picasso did not resort to polychrome. ${ }^{6}$

Graffite at Cap-Martin was remarkable in its refusal to the use of polychrome. More importantly, it points to the separation of color and drawing on the picture plane. This last feature will be a constant thereafter.

These procedures will bring about a change in the structure of the works.

The sinuous calligraphy of the figures is inscribed over the color patches. Formally, this separation implies that preeminence is given to the drawing against the background, over which it appears to float. Through this solution, the figure is enhanced, thus appearing as an independent, outlined element on the surface. As a result, certain elements of the figuration tend gradually toward an iconic role.

\section{Dualism: the other}

As displayed extensively by Le Corbusier in several publications and lectures, images of "the solar journey of 24 hours", "the Modulor", "the law of the meander", "the diagram of the essential joys" are recurrent, both in his paintings and architecture.

These diagrams, sketches and synthetic drawings had been set as icons or symbols since an early age. As modern glyphs, derived from a crude stroke of color, usually black, its origins are not the graphic exercise, but the concept. They illustrate necessary abstractions in the architectural and urban debate that dates back to the 1930s. They clearly play a communicative role. These glyphs had first appeared in publications; later on, they invaded other spheres.

Unlike these, the image of the hand will not achieve a final result until very late. In various manifestations of the period, it appears intertwined, in a clear allusion to communion. It is often accompanied by rocks, shells, bones, small objects and, on many occasions, by the curved lines of the female body.

The touch, the handle of forms of the natural world by the hands, the perception of textures, the measurement of weight seem to be the privileged way to apprehend the environment chosen by the architect, as if it demanded a reunion with something more primal and fundamental. ${ }^{7}$

We notice that a radical change has been brought about, especially when we consider the prominent place given to vision and optics during the 1920s in L'Esprit Nouveau, the desired purist objectivity for painting and the architecture seen as "the masterful, correct, and magnificent play of volumes brought together in light".

The dualism that dominates his art elects a companion to the image of the hand: the female body, a privileged object to knowledge. Dualism was a permanent attribute of Le Corbusier thought, which origins are far beyond the concerns of this paper. However, it is important to note that a dualistic view of the world, related to natural

\footnotetext{
${ }^{6}$ Id., p. 4.

${ }^{7}$ The presence of tactile attributes in the work of Le Corbusier is differently developed by Monteys, Xavier. "Tres apuntes sobre la presencia de lo tactil en la obra de Le Corbusier”. In: Torres, Jorge (Ed.). Le Corbusier Mise au Point. Memorias Culturales. Valencia: General de Ediciones de Arquitectura, pp. 182-194.
} 
processes and in accordance with a form of primitive thought - mythical and circular —, seems to emerge more forcefully in his art during the postwar period, as an alternative to progress, speed, visual stimuli, and the arrow of time of the civilisation machiniste.

In view of the image of the hand, the other seems to be a figure also found in his paintings, the winged figure, half woman and half beast (Fig. 03), emerging from the recollection of the North African experience. ${ }^{8}$

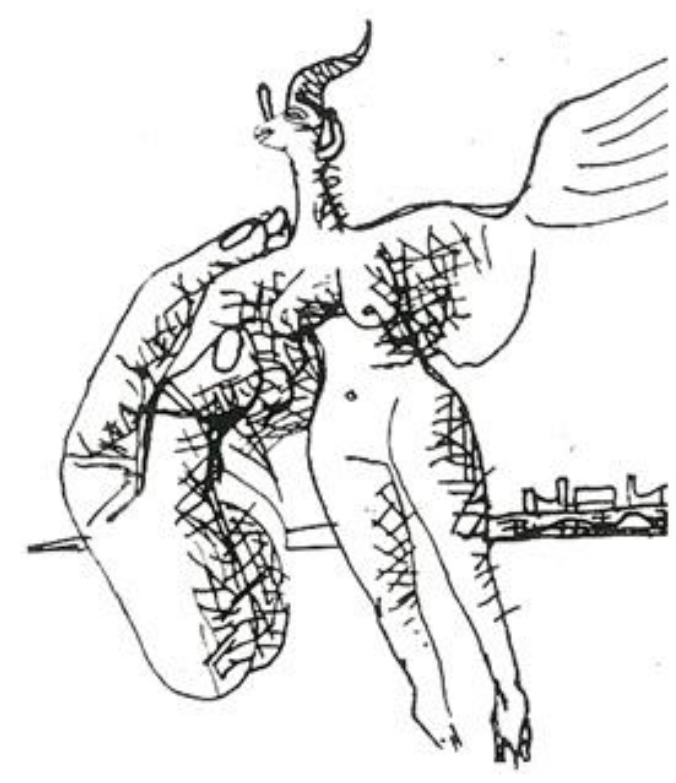

3. Cover of Poésie sur Alger. $1^{\text {st }}$ ed. Paris: Falazie, 1951

In the posterior lithographic album Petites Confidences, printed in 1957, the architect called this figure a Licorne, but this name is inaccurate. Its genesis clearly seems to be derived from the increasingly frequent exercises on the female body. It also resonates "les meandres" that so much impressed the architect.

Usually horizontally outlined, with its wings safeguarded on its body, the design does not correspond to a figure in flight, but to an indelicate suspension, as if it was carried by the wind. The rigidity of the image was very similar to that found in the series of sculptures Icône, made together with Joseph Savina in later years ${ }^{9}$.

Similarly to Walter Benjamin's description of Paul Klee's Angelus Novus, Le Corbusier outlines the figure always facing back towards the wind that drives in the opposite direction. However, unlike Klee's painting, nothing suggests the storm "that irresistibly impels the future to which his back is turned, while the pile of debris grows to heaven". ${ }^{10}$ In Le Corbusier the meaning is different. The images suggest a detachment of the worldly

\footnotetext{
${ }^{8}$ Von Moos, Stanislau. "Mariage des Contours". In: Oppositions 19-20. Cambridge, Massachusetts: MIT Press, 1980, pp. 87107.

9 To a analysis of this collaboration see Le Couédic, Daniel. Joseph Savina, l'improbable compagnon de route", in Le Corbusier : L'œuvre plastique, Paris, Fondation Le Corbusier et Éditions de La Villette, 2005, p. 26-53

${ }^{10}$ Benjamin, Walter. "Sobre o conceito de História". Magia e técnica, arte e política: ensaios sobre literatura e história da cultura. $7^{\text {a }}$ ed. São Paulo: Brasiliense, 1994, p. 226.
} 
experience and the tragedy represented by the historical time. It appears subject to the volatility of natural phenomena.

As indicated by Tafuri, ${ }^{11}$ the detachment from the worldly experience, implied by the over-flight vision, is a theme dear to Le Corbusier. It is recurrent since his first experiences with airplanes during the voyage to South America in 1929.

The importance of the flight experience has been extensively pointed out as a catalyst of a new attitude toward urban phenomenon: the changes on the scale of its urban plans, the confrontation between building and landscape, the comprehension of architecture in a territorial sense. However, very little attention has been given to the flight as a cognitive experience defined by a particular time.

We clearly see that the contemplation of the physical environment from an airplane is marked by a "relative slowdown in look" - as if it had occurred during a longstanding period, when the vicissitudes of the everyday experience were almost indifferent to the observer. The perspective provided by the airplane implies an "apparent suspension of speed" that equals the activities of human labour and primitive nature.

Also the incidence of sunlight on the surfaces seen from above works differently from that observed from the ground. The shades and shadows seem to blur the clear distinctions between architecture and nature, as if all phenomena were unified and reduced to a geological scale: scars, breaks and stratification on a heterogeneous surface.

It is no accident that the extensions observed from the top of the mountains in the Jura during his formative years are an emotional bond that anticipates this process. The memory will favor a realistic attitude toward the phenomena of nature, away from any esoteric bindings or surrealistic overtones.

Would it not be significant that the abandonment of the objectivity of the visual experience of purism - to the detriment of an appreciation of the tactile aspects of the world mediated by the hand - coincides with a new statute of "looking", marked by the contemplation of the extensions and the awareness of the quality of surfaces?

Would it not be the games with scales - so characteristic of his work - a means to make sense of these two extremes, analogous to the photos of water and sand taken on the beach of Le Piquey (Fig.04), which resemble the descriptions of landscapes seen above?

Le Corbusier seems to suggest that the nature and the technical problem should be unified in a common time.

It is not at this precise period that the role assigned to nature as a homogeneous background to his architecture was abandoned in favor of an active incorporation, almost resonant, such as the coverage of the Unite in Marseille so much testifies?

Are the paths leading to this consciousness of the story of the winged figure?

\footnotetext{
${ }^{11}$ Tafuri, Manfredo. "Machine et mémoire: The City in the Work of Le Corbusier". In: Brooks, Allen H. (Ed). Le Corbusier BROOKS, Allen H. (ed). Princeton, New Jersey: Princeton University Press, 1987, pp. 203-228.
} 


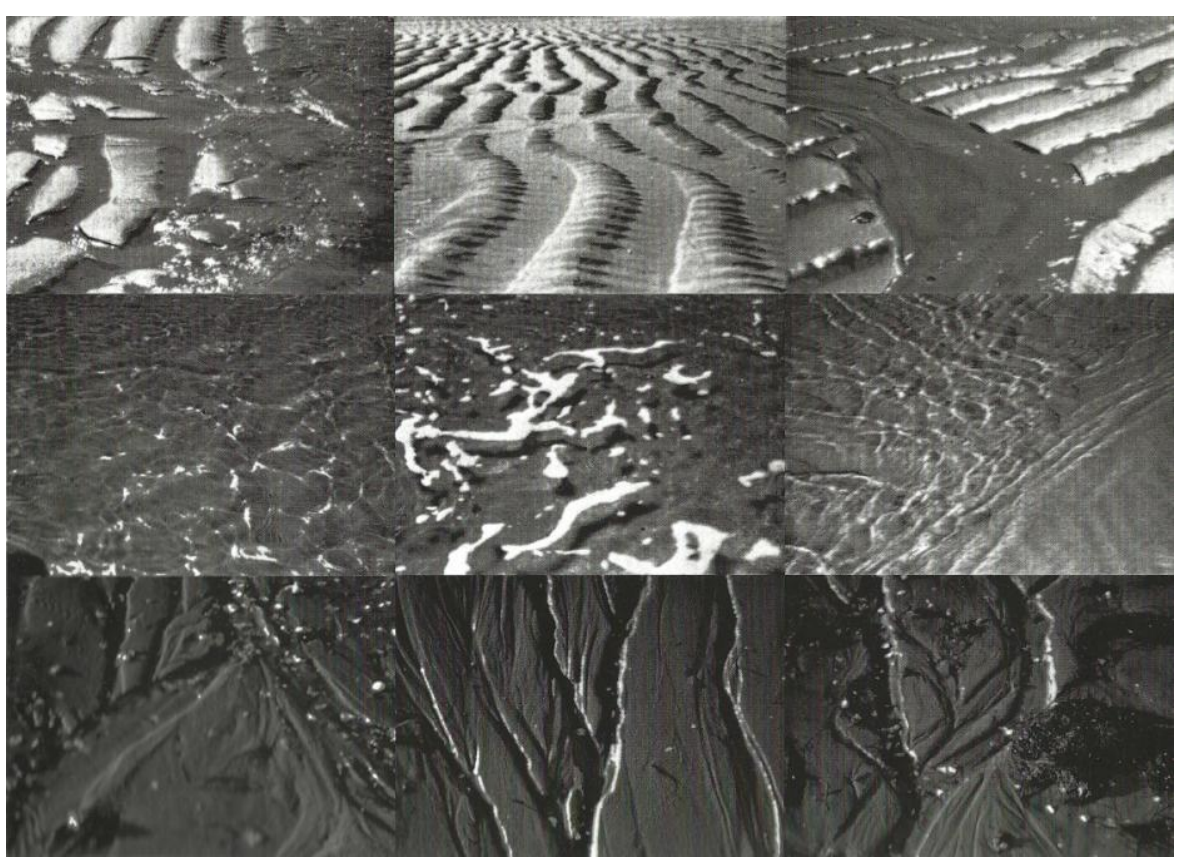

4. 16mm film camera. Le Piquey between 1936-37. FLC

\subsection{Two panels}
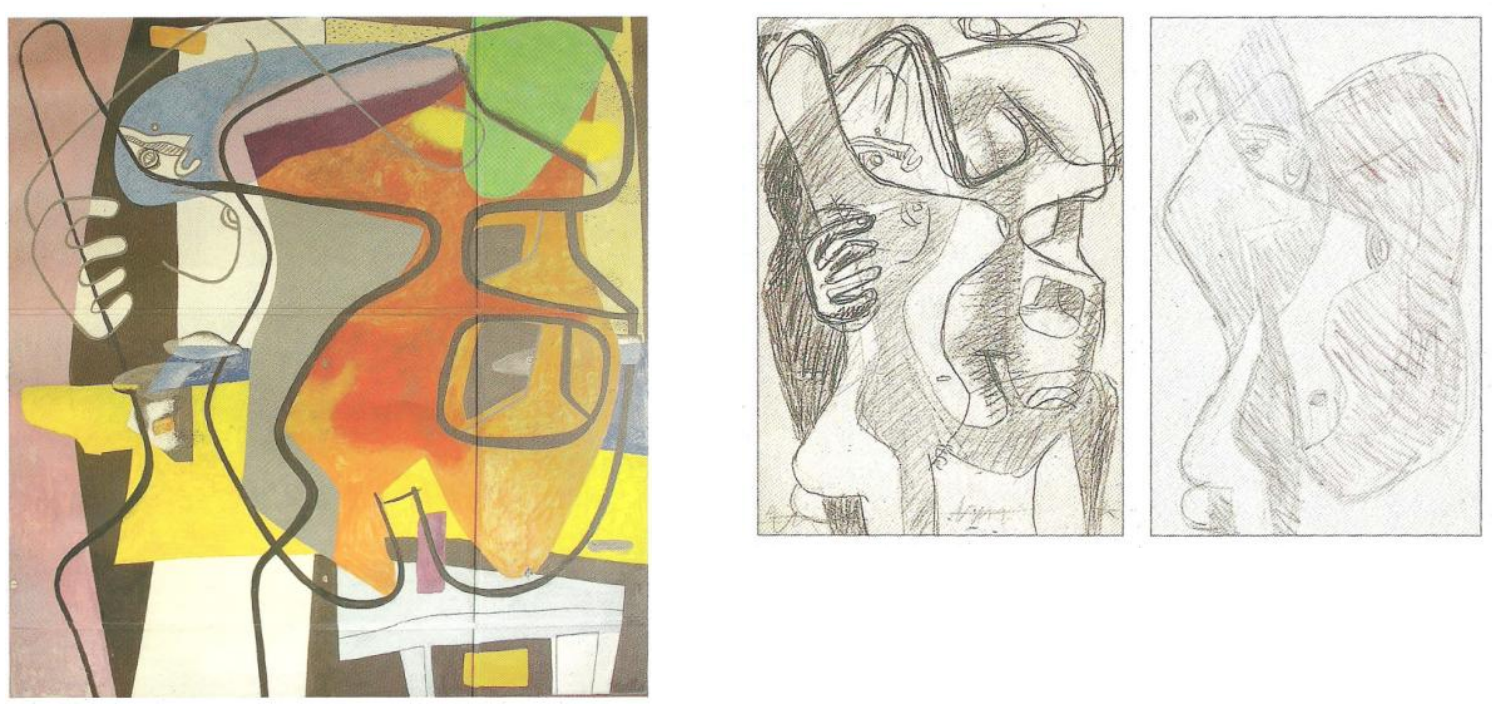

5. Mural at 35 rue de Sèvres. Photo: Marie-Odile Hubert, 2006

6. Étude de la gravure pour 5 femmes. FLC 4028

7. Étude Femme et coquillage. Crayon on paper. FLC 4202

After the Easter holidays of $1948,{ }^{12}$ the employees of the atelier at 35 rue de Sèvres were surprised by a painting (Fig. 05) of $3.82 \times 3.50 \mathrm{~m}$ on the backplate that covered the end wall of the workspace.

The panel was derived from a series called Femme et coquillage (Figs. 06 and 07), widely documented in sketches in pencil and crayon and later reproduced on other media such as engraving and oil.

\footnotetext{
${ }^{12}$ As told by Roger Aujame in "La Peinture murale, 35 rue de Sèvres à Paris". Foundation Le Corbusier.
} 
The dualism is evident. The contours - the mariages des contours - merge the irregular and sinuous shapes of a female figure with a shell. Wrapped in a hug, anchored by a hand that rests or deliver, the female figure occupies the side with nocturnal colors, close to blue and purple, whereas the shell is demarcated with a solar and lively orange.

The theme of the mural at the Pavillon Suisse of the Cité universitaire in Paris in 1948 (Fig. 08) was more elaborate.

With massive dimensions of $10.63 \times 3.42 \mathrm{~m}$, one half of the wall is occupied by the representation of the myth of the Minoan labyrinth. As a metaphor for architecture itself, the labyrinth serves as remembrance of a troubled, irregular path, in a clear allusion to the tribulations of human experience.

It would be appropriate to think of the labyrinth as an antagonist to the meander's law. The meander illustrates the operation of natural laws, the relentless force of nature that overcomes any obstacle. The labyrinth points to the uncertainties and dilemmas of the worldly experience in which men intended to get lost.

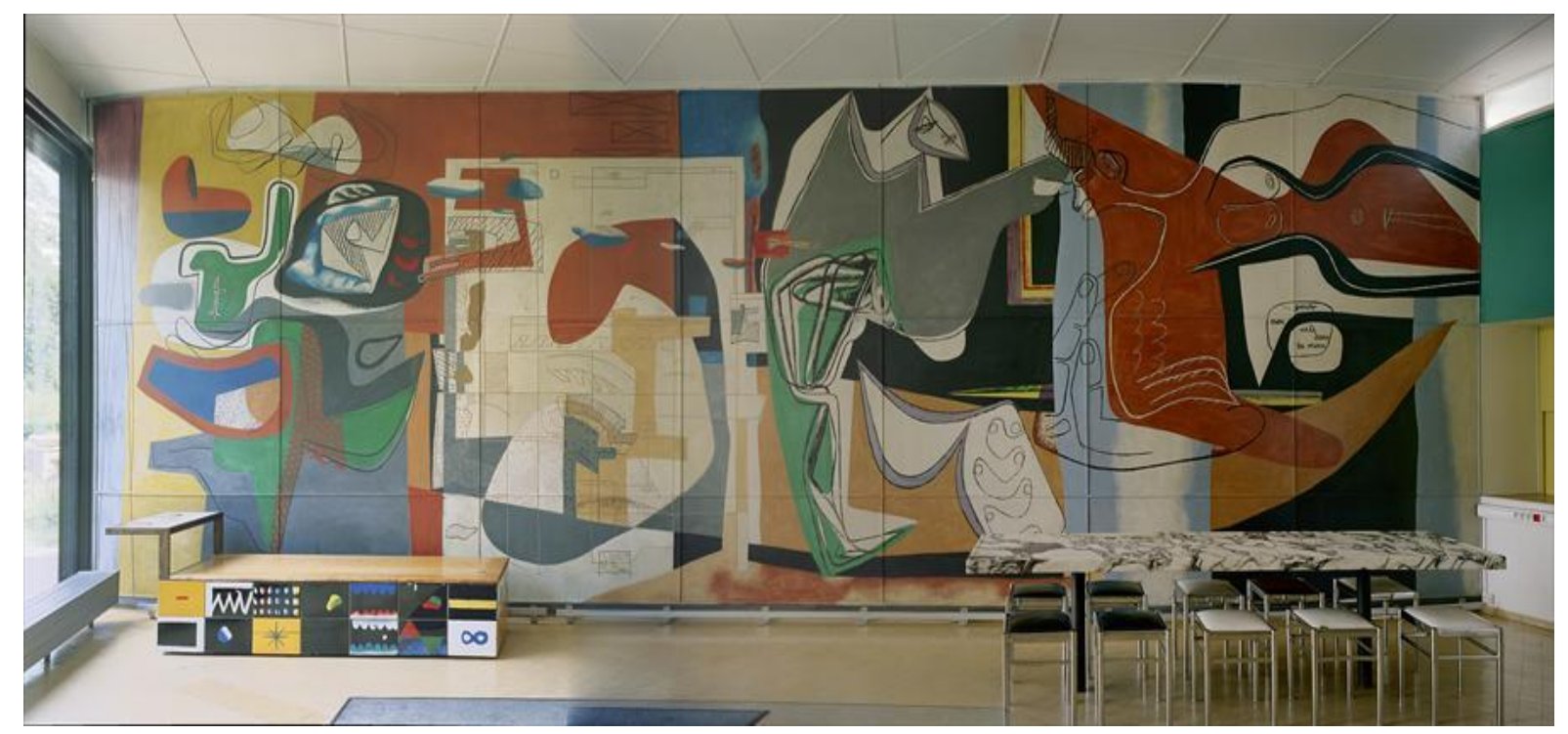

8. Cité universitaire, Pavillon Suisse. FLC/DAGP.

The bull and woman, separated by the labyrinth, re-propose most clearly the dualism presented through the wall in rue de Sèvres. This dualism, however, has deeper nuances. Half bull, half man, the beast that inhabits the labyrinth, the Minotaur, was the result of the incestuous relation between Pasiphaë, the Queen of Crete, and the bull sent by Poseidon as an offering to King Minos. This unholy genesis would not have gone unnoticed to Le Corbusier.

Richard A. Moore suggests that the female figure is Pasiphaë, the Queen of Crete and the goddess of the moon. ${ }^{13}$ Although the shape of the head resembles a crescent moon, it is worth noticing that in his hands lies the ball of thread associated with Ariadne. As retold through the myth, the thread was provided by Ariadne to guide Theseus through the labyrinth, so he could kill the Minotaur. Even when confronted with the subsequent lithography, Ariane et Pasiphä (1961), the similarity in the design of the figures does not allow us to definitely denominate her.

\footnotetext{
${ }^{13}$ Moore, Richard A. "Alchemical and Mythical Themes in the Poem of the Right Angle". Oppositions (Winter 1980): 110114 Cambridge : MIT Press for The Institute for Architecture and Urban Studies, 1980.
} 
The other half of the panel is dominated by a delicate arrangement of the image of a winged female resting on one hand. It suggests a more generous communion between opposites, in a clear opposition to the violent dualism of the Minoan myth.

The prominent position of these two figures within the symbolic system of Le Corbusier is reinforced by the passage taken from the initial strophe of the poem Autre Eventail Mme. Mallarmé, by poet Stéphane Mallarmé. It is inscribed alongside the figures: "Garder mon aile dans ta main". ${ }^{14}$

The unusual resort to a literary reference explicitly reaffirms that the nature of the game developed by the two images has a symbolic horizon that craves for definition. ${ }^{15}$

These images seem to synthesize the two attitudes that govern the work of Le Corbusier thereafter.

On the one side, there is the need to anchor the plastic work in a sphere related to the expression of human labor, which is symbolized by the hand. On the other extreme, the need to provide the plastic work with a final horizon different from the contingency of the present. This is symbolized by the winged figure in flight.

\section{Le Poème de L’Angle Droit}

In Le Poème de L'Angle Droit (Fig. 09) we can find the key elements of Le Corbusier's symbolic system. The poem organizes the constellation of symbols that permeates his work.

It was written between 1947 and 1953, when the production of the two murals also took place. Its subjects will be fully incorporated into the lithographs of the book.

The tone of this work is confessional, as suggested by the architect's calligraphy and ink sketches. The book records the notes and drawings made during successive trips between Paris, Marseille and Chandigarh.

Le Corbusier uses the idea of iconostasis to spatially organize the 19 lithographs that make up the poem.

Iconostasis is a set of religious icons organized within an interchangeable orthogonal grid, arranged between the nave and the altar of Orthodox churches. In a way, it marks the separation between the mundane sphere, the ship, and the sacred sphere, the altar. In this orthogonal grid the position of each icon is precisely determined by the religious narrative to which the group relates. The intention of the architect seems to be similar.

\footnotetext{
${ }^{14}$ The complete strophe in Mallarmé's poem reads as follows: "O rêveuse, pour que je plonge,/ Au pur délice sans chemin,/ Sache, par un subtil mensonge,/ Garder mon aile dans ta main".

15 On the relationship between literature and architecture in the work of Le Corbusier, see: Calatrava, Juan. "Referentes literários en el pensamiento de Le Corbusier”. In: Torres, Jorge (Ed.). Le Corbusier Mise au Point. Memorias Culturales. Valencia: General de Ediciones de Arquitectura, pp. 126-161.
} 


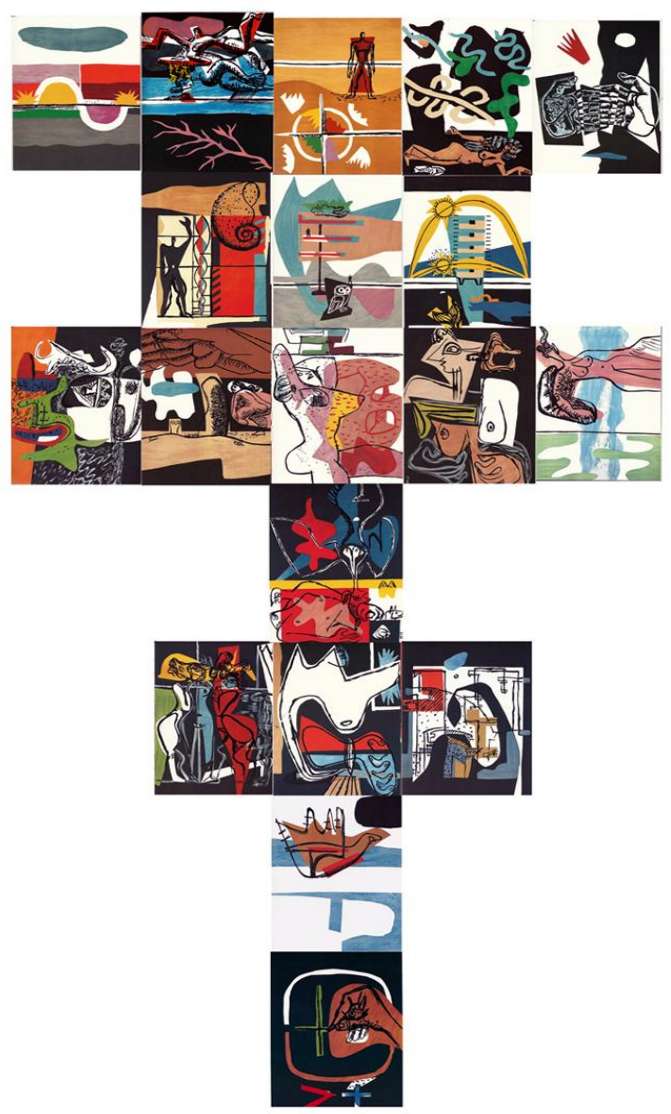

9. Le Poème de L'Angle Droit, author's montage.

The poem's iconostatic matrix is composed by seven lines, corresponding to the seven themes guiding the arrangement of the lithographs: environment, spirit, flesh, fusion, character, offering, and instrument.

The organization of the poem suggests successive synthesis from top to bottom.

It evolves around the duality represented by the dominant images of the hand and the winged woman, and is complemented by the previously elaborated symbols such as the sinuous calligraphy of the "law of the meander", the solar journey of 24 hours, the diagram of the essential joys and the Modulor.

On top we can see the eternal succession of natural-geological phenomena indifferent to human labor - for which architecture appears as a more accurate metaphor.

Below we see the record of the unpredictability of everyday life and the vicissitudes of the human condition.

The lithographs of the Femme et coquillage series, of the bull, the labyrinth, and of Pasiphaë/Ariadne attend fully in the iconostasis.

The presence of these figures suggests an even more intimate connection, especially when we think that the third row of the iconostasis, once ordered, displays an arrangement which is similar to the one on the wall of the Pavillon Suisse: the bull on the far left, Femme et coquillage replacing Pasiphaë/Ariadne, and the winged figure resting on a hand at the far right.

If we consider that the lines follow one another in successive syntheses, we have the first three re-proposing the dualism previously studied, with the Modulor and the principles of modern architecture and urban planning as a 
link or interface between the man's faith in instrumentality and the nature's call for detachment of the everyday experience.

However, from the fourth line, called fusion, we move into the territory where these images will be reworked, and we arrive at the genesis of the icon, which is our matter of concern in this paper.

The duality finds its form in the figure of the Open Hand (Fig. 10), elected as a synthesis of the entire symbolic system, and precedes a new operability proposed in the last lithograph, the right angle.

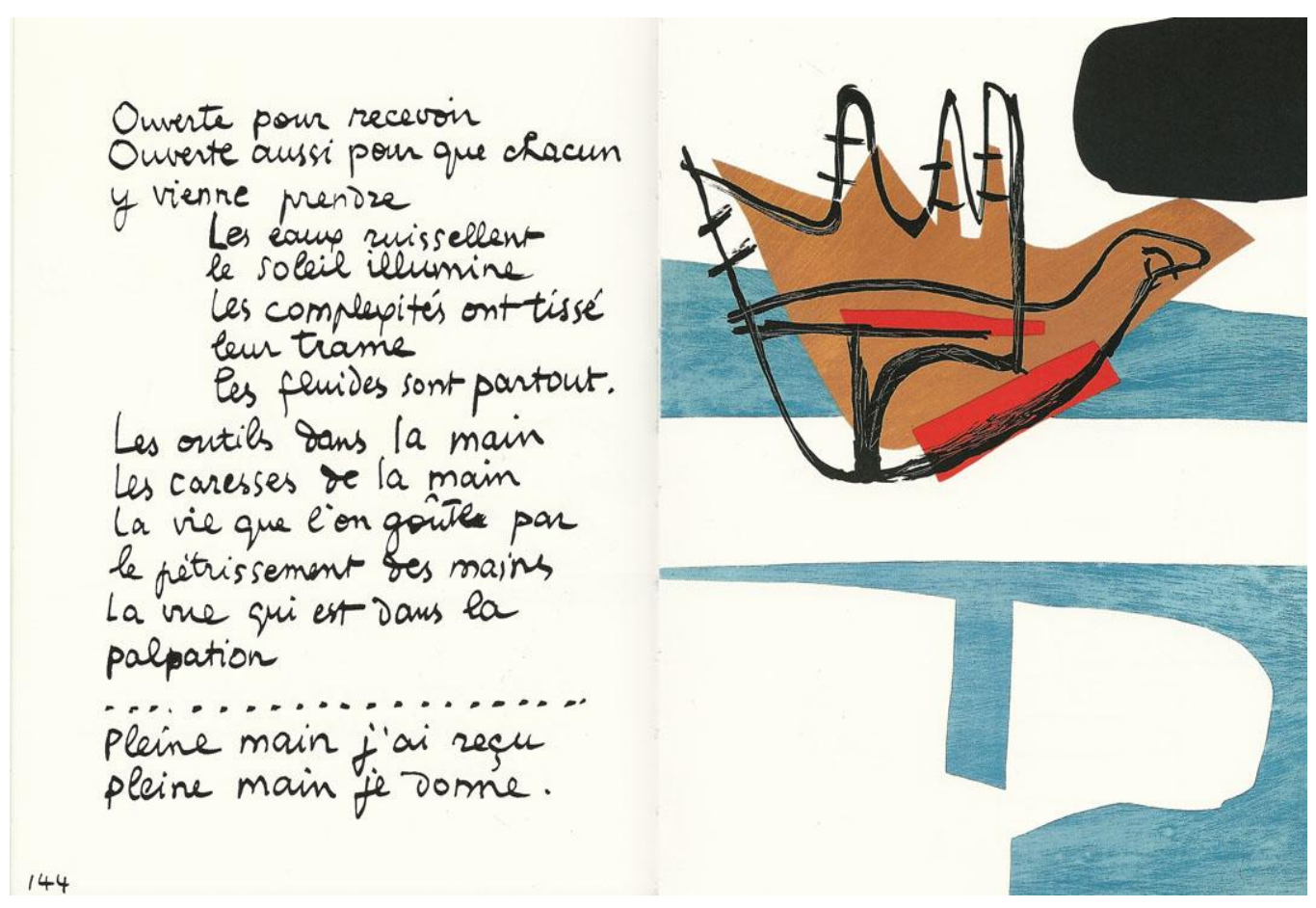

10. The Open Hand. Le Poème de l'Angle Droit. $1^{\text {st }}$ ed. Paris: Verve, 1955.

The hand is drawn in suspension. The three intermediate fingers are set vertically, and the edge fingers are opposed to them.

This opposition of extreme fingers does not correspond to the natural position of a hand, as in the design of the winged figure on the wall of the Pavillon Suisse. This strange position — almost impossible — incorporates his double, the winged figure: a hand appears suspended in the air like the silhouette of a flying bird.

The poem thus retells the genesis of this figure, drawn as a to reconcile the two different attitudes having mastery over his work.

A drawing dating back to the 1950s (Fig. 11) suggests another genesis for the image of the Open Hand. This drawing is on one of the notebooks that the architect had brought to Bogota during the commission of the city's Pilot Plan. The Open Hand appears to derive from a sketch depicting a group of five women gathered in circle, one of them lying on the front. 


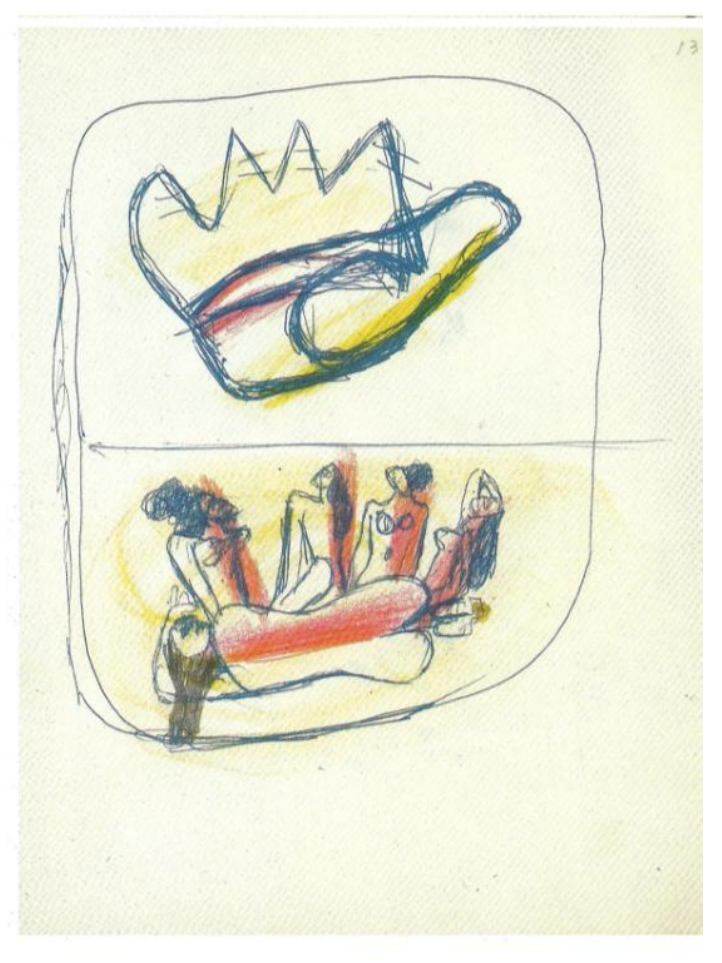

11. Sketch from the Bogota's notebook. FLC.

This genesis does not fit the narrative outlined in Le Poème de L'Angle Droit and in the mural at the Pavillon Suisse in the Cité universitaire.

What is suggested here is that the precise definition of this drawing indicates an earlier formulation. The nature of the scene seems to confirm that the intention underlying the hand symbol is similar to the transmission of experience that can be deduced from the congregation wheel. It has a communicative intent.

The poem's tone is personal, whereas the poem's structure is, conversely, highly elaborate. The iconostasis suggests a textile in which the symbols are collected, retold and worked. Path of the memory and intellectual adventure at once, it is not related to any defining moment, nor is contaminated by any particular place and time - as an example, it incorporates attributes collected from the Indian landscape, but excludes those symbols explicitly bound to the Hindu tradition, like the Ashoka Chakra and the swastika, symbols that later on will be incorporated into the works of Chandigarh.

Is not it strange that no technical apparatus appear? No plane or automobile, no factory or a modern buildingjust an ordinary fishing boat instead of an ocean liner?

The need to move the language, passing successively from one image to another, dominates the nature of the symbolism permeating Le Corbusier's work.

Clarity of language cannot be claimed. On the contrary, the structure of the poem appears as a metaphor for the labyrinth. A labyrinth without Ariadne's thread. 


\section{Garder mon aile dans ta main}

The architectural works belonging to the period of the development of the poem (1947-1953) seem to reflect the oscillation between these two extremes. The expression owes much to the antagonistic struggle between the materiality of the gross artifact and the spatiality avid to expand its boundaries beyond the object itself.

As demonstrated in Le Poeme de L'Angle Droit, what governs the symbol in the work of Le Corbusier is its particular experience. It is no coincidence that the poem's tone is confessional, and that the travel records dominate various drawings accompanying lithographs. The trip works as a metaphor for personal experience. Its importance is reaffirmed several times since Le Corbusier's trip to Asia Minor and Eastern Europe in 1916, the so-called Journey to the East. This symbolism is fed by these experiences, but mostly by the voyages to South America, North Africa and especially India.

The image of the open hand would appear materialized as a monument in the Plan for Chandigarh's Capitol, in Punjab, India (Fig. 12).

Le Corbusier took on the task of designing the representative buildings of the city: the Secretariat, the General Assembly, the High Court and the Government Palace, the latter ending up not being built. These buildings make up the capitol city, located on the outskirts of the urban plan.

The city plan, originally developed by American urban planner Albert Mayer, was just reviewed by the architect, and was implemented by Pierre Jeanneret and the couple formed by English urban planner Maxwell Fry and the anthropologist Jane Drew, the last two associated with the MARS Group (Modern Architectural Research Group), the English section of the CIAM.

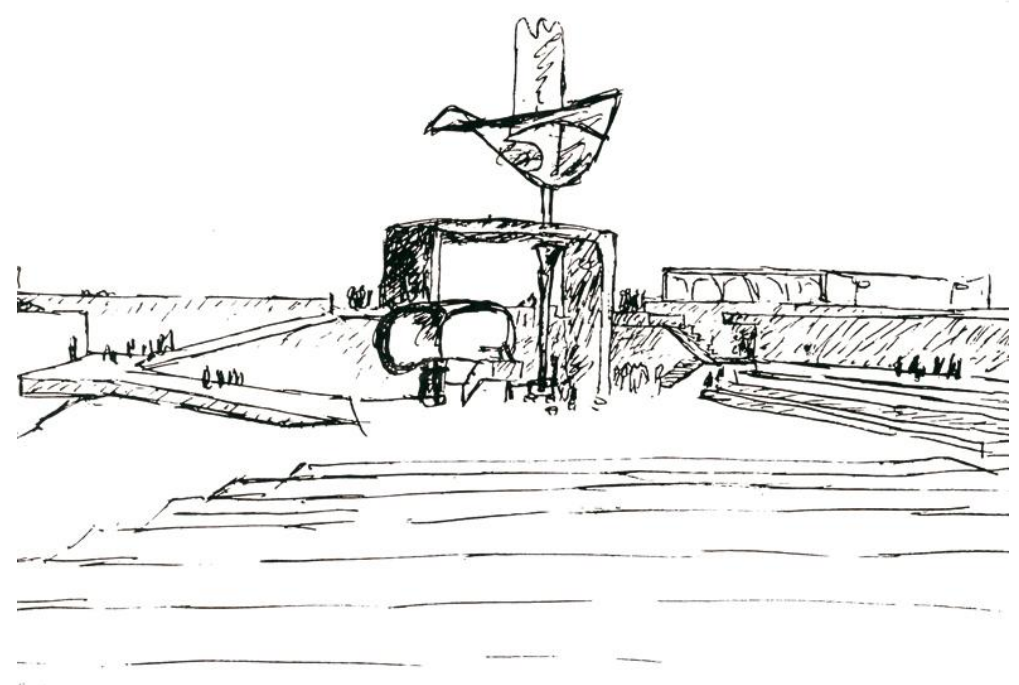

12. Sketch of the Open Hand in Chandigarh.

In: Mein Werk/L'Atelier de la recherche patiente. $1^{\text {st }}$ ed. Paris: Ed. Vincent Fréal, 1960

The difficulties and specific political connotations that this symbol assumed in the Indian context are not within the concerns of this paper. Its realization would take more than twenty years after the end of the main buildings of the capital, after the death of the architect and the Prime-Minister Nehru. We are more concerned with the political connotations intended by the architect, its internal position in the body of his work, as the culmination of its iconic and symbolic concerns. 
The architecture of Chandigarh's monument Open Hand was intended as a metaphor for the contradictions upon which the architect's work is anchored.

The symbol emerges as a consciousness that his creative activity, as opposed to what his work could have suggested until the mid-1940s, could no longer be anchored in the technical dimension of the industrial civilization. The work of art should point to a time different from that of the machinist civilization. The univocal time when all processes will be unified, the perfect image of the machine, would be incompatible with the fullness of human experience to which his architecture pretends.

Language should look for other purposes, a new, open instrumentality.

Not accidently, another monument - as the former in memory of Vaillant-Couturier (Fig. 01) - concentrates the dilemmas faced by Le Corbusier during the long and patient research. The intent of the architect in both cases is communication. It is significant of his change of attitude towards the possibilities opened by modernity.

In 1937, Villejuf, intended with the speed provided by the automobile, generates the dynamism of the composition and breaks away with the immobility of disinterested contemplation.

In Chandigarh, the detachment from the surroundings and other visual stimulus that allows contemplating the wind transform one image into another.

Suspended on a metal pole, its position in the Capitol marks the space symbolically called Pit of Consideration. It is detached from the immediate surroundings and alludes to the necessary halt before action.

This is the context for the Open Hand monument. Its design reaffirms the initial directions described in the poem, as well as the genesis suggested herein.

The pole rests on a metal roller that allows the sculpture to move freely, driven by the wind.

The constant change in the wind direction is responsible for the transformation from one image into another: the imperious gesture of the hand marking their presence along the skyline, and the delicacy of the wing that moves in the wind.

In "garder mon aile dans ta main".

\section{Acknowledgements}

Prof. José Tavares Correia de Lira (FAUUSP — São Paulo, Brasil).

Guillherme Pianca, Stephanie Guerra and Bruno Schiavo, for their comments.

\section{Source of images}

01, 02. extract from: : Mein Werk/L'Atelier de la recherche patiente. $1^{\text {st }}$ ed. Paris: Ed. Vincent Fréal, 1960.

03. extract from: Poésie sur Alger. $1^{\text {st }}$ ed. Paris: Falazie, 1951.

04. $16 \mathrm{~mm}$ film camera. Le Piquey between 1936-37. FLC

05. Marie-Odile Hubert, 2006. FLC. DAGP.

06. Foundation Le Corbusier. FLC 4028

07. Foundation Le Corbusier. FLC 4202

08.Foundation Le Corbusier. FLC/DAGP

09. author's montage using the pages of Le Poème de l'Angle Droit. $1^{\text {st }}$. ed. Paris: Verve, 1955. 
10. extract from: Le Poème de l'Angle Droit. $1^{\text {st }}$. ed. Paris: Verve, 1955.

11. Sketch from the Bogota's notebook. Foundation Le Corbusier.

12. extract from: : Mein Werk/L'Atelier de la recherche patiente. $1^{\text {st }}$ ed. Paris: Ed. Vincent Fréal, 1960.

\section{Bibliography/References}

Benjamin, Walter: "Sobre o conceito da História". Magia e técnica, arte e política: ensaios sobre literatura e história da cultura. ed.7. São Paulo: Brasiliense, 1994. p.226

Besset, Maurice (org.). Le Corbusier sketchbooks. Nova Iorque : Architectural History Foundation Cambridge, Mass. : MIT Press, 1981

Brooks, H. Allen. Le Corbusier's Formative Years. 1.a ed. Chicago. University of Chicago Press, 1997

Calatrava, Juan. "La plastica de un arquitecto". In: Salvador Guerrero (Ed.), Una Casa-Un Palacio. Madrid 1928. Exhibition catalog. Madrid: Publicaciones de la Residencia de Estudiantes, 2010, pp. 182-183

Calatrava, Juan. "Referentes literários en el pensamiento de Le Corbusier”. In: Torres, Jorge (Ed.). Le Corbusier Mise au Point. Memorias Culturales. Valencia: General de Ediciones de Arquitectura, pp. 126-161

Cohen, Jean-Louis (org.). Le Corbusier-An Atlas of Modern Landscapes. Londres: Thames \& Hudson, 2013.

Colomina, Beatriz. Privacy and Publicity. Architecture as Mass Media. $1^{\text {st }}$ ed. Cambridge, Massachusetts: MIT Press, 1996

Corbusier. Doctoral thesis. Director: Adolfo Gonzalez Amezqueta. Escuela Técnica Superior de Arquitectura de d'Aujourd'hui, 1935

Eléments d'une doctrine d'urbanisme pour l'équipment dela civilisation machiniste. Paris: Ed. L'Architecture Foundation Le Corbusier: “La Peinture murale, 35 rue de Sévres à Paris” Foundation Le Corbusier, 2009 general bibliography:

L'Architecture d'aujourd'hui. Special issue “Le Corbusier”. Paris: Editions L'Architecture d'aujourd'hui, 1948

Le Corbusier. "Cornotions Sudamericaines. Introduction à un urbanisme sensible", in La Ville Radieuse.

Le Corbusier. Aircraft. 1.a ed. Madrid: ABDA, 1987

Le Corbusier. Ouevre complète, 1929-1934. Zurich: Les Édition d'architecture Erlenbach-Zurich;

Le Corbusier. Precisions sur le état présent de L'architecture et de urbanisme.1.a ed. Paris: G.Crés et Cie., 1930

Le Corbusier: Le Poème de l'angle droit. 1st ed. Paris: Verve, 1955

Le Corbusier: Mein Werk/ L'Atelier de la recherche patiente. 1st ed. Paris: Ed. Vincent Fréal, 1960

Le Corbusier: Poésie sur Alger. 1st ed. Paris: Falazie, 1951

Le Couédic, Daniel. Joseph Savina, l'improbable compagnon de route", in Le Corbusier : L'œuvre plastique, Paris, Fondation Le Corbusier et Éditions de La Villette, 2005, p. 26-53

Lucan, Jacques. Le Corbusier. Une encyclopedie. 1.a ed. Paris. Centre Georges Pompidou, 1987

Madrid. Madri, 1992

Mark Antliff, Avant-Garde Fascism : The Mobilization of Myth, Art, and Culture in France, 1909-1939. Durham, NC: Duke University Press, 2007

Martins, Carlos A. Ferreira. Razón, ciudad y naturaleza. La génesis de los conceptos em El urbanismo de Le 
Mary McLeod "Le Corbusier and Algiers"In: Oppositions 19-20. Cambridge, Massachusetts: MIT Press, 1980, pp. 55-85

Monteys, Xavier. "Tres apuntes sobre la presencia de lo tactil en la obra de Le Corbusier". In: Torres, Jorge (Ed.). Le Corbusier Mise au Point. Memorias Culturales. Valencia: General de Ediciones de Arquitectura, pp. 182-194

Moore, Richard A. "Alchemical and Mythical Themes in the Poem of the Right Angle". Oppositions (Winter 1980): 110-114 Cambridge : MIT Press for The Institute for Architecture and Urban Studies, 1980

Tafuri, Manfredo. Projecto e Utopia. Lisboa: Presença, 1985

Tafuri, Manfredo. Teorias e História da Arquitectura. 2.a ed. Lisboa: Editorial Presença,1988

Tafuri, Manfredo: "Machine et mêmoire: The City in the Work of Le Corbusier". in, Le Corbusier. Brooks, Allen H.1st ed. Princeton University Press. Princeton, New Jersey, pp.203-228

Valéry, Paul. Introdução ao Método de Leonardo da Vinci. 1.a ed. São Paulo: Editora 34, 1998

von Moos, Stanislau: "Mariage des Contours". in.Oppositions 19-20. Cambridge, Massachusetts: MIT Press, 1980. pp. 87-107

Von Moos, Stanislaus. Elements of a Synthesis. Rotterdam: 010 publishers, 2009 